\title{
Sympathovagal Imbalance in Type 2 Diabetes - Role of Brainstem Thyrotropin-Releasing Hormone
}

\author{
Yang Hong \\ Additional information is available at the end of the chapter \\ http://dx.doi.org/10.5772/56541
}

\section{Introduction}

Type 2 diabetes (T2D) is the world's fastest growing disease with high morbidity and mortality rates. The potential to develop effective therapies is severely limited by poor understanding of mechanisms underlying the etiology and progression of T2D.

Increasing evidence suggests that the brain plays a key role in regulating metabolism [1, 2]. In particular, the exquisitely precise adjustments in the sympathetic and parasympathetic outflow by the brain are critical for maintaining metabolic homeostasis. Enhanced sympathetic drive and impaired vagal efferent function contribute to multisystemic pathophysiology of T2D, including reduced insulin secretion, gastroparesis, hypertension, and high cardiovascular mortality [3-6]. The aim of this chapter is to emphasize the importance of the brainstem, which contains sympathovagal regulatory nuclei, in the regulation of metabolism, especially in T2D conditions. I focus on the role of $b$ ainstem thyrotropin-releasing hormone (TRH) in the physiology of autonomic control of metabolism and the pathophysiology of autonomic dysfunction in T2D. TRH is a three amino acid neuropeptide originally discovered in the hypothalamic paraventricular nucleus. Brainstem raphe nuclei are another major locus of TRH neurons, which send TRH-containing projections to innervate brainstem and spinal sympathetic and vagal motor/premotor nuclei. TRH acts at these nuclei to control sympathetic and vagal descending pathways involved in regulating food intake, blood pressure, heart beat, pancreatic insulin secretion, and gastrointestinal secretion/motility. Our studies found an impaired brainstem TRH action on the vagal efferent control in a T2D rat model. Understanding brainstem disorders responsible for the sympathovagal imbalance in T2D is fundamental for revealing the mechanism of T2D development. Targeting on restoring a balanced sympathetic-vagal regulatory function of brainstem TRH could be a new direction for the prevention and therapy of T2D. 


\section{The autonomic nervous system is a major pathway mediating the brain regulation of metabolism}

\subsection{Sympathovagal motor and premotor neurons in the brainstem and the spinal cord}

The sympathetic and parasympathetic nerves are the two functionally opposite branches innervating visceral organs to mediate and integrate the central control of body metabolism. While numerous studies have well established the metabolic regulatory center of the hypothalamus, more and more recent studies revealed the importance of the brainstem in the neuroanatomically distributed control of energy balance [7]. Studies by Grill et al using the chronically decerebrate rat models demonstrated that the brainstem, also called hindbrain, contains an essential mechanism detecting metabolic need and exhibiting autonomic response to the metabolic challenge [7-9]. The brainstem is sufficient to mediate many aspects of the energetic response to starvation and maintain the normal glucose levels [10]. Indeed, the brainstem contains neural circuits receiving and sensing peripheral neural, nutritional and hormonal signals, and more importantly, including sympathovagal motor neurons and premotor neurons responding to these signals.

\subsubsection{The Dorsal Vagal Complex (DVC) and the nucleus Ambiguus (Amb)}

The DVC is composed of the dorsal motor nucleus of the vagus (DMV) and the nucleus tractus solitarii (NTS) (Fig.1), which respectively contains somata of parasympathetic efferents projecting to the visceral organs [11-13] and neurons receiving vagal afferent input from the viscera [14]. The nearby area postrema (AP) and portions of the NTS, where the blood-brain barrier is incomplete, can be the portal of entry for circulating hormones entering the brain [15]. The Amb contains vagal motor neurons projecting to the thoracic organs as well as the upper gastrointestinal (GI) tract and the pancreas (Fig. 1).

The DMV receives powerful influence from higher brain levels. Stimulation of the neurons in the paraventricular nucleus of the hypothalamus (PVN) activates DMV neurons projecting to the gut [16,17]. The ventromedial hypothalamic nucleus (VMH), which contains glucose sensitive neurons, also has direct connections with DMV and NTS [18,19]. In addition, the DMV receives descending connections from the locus coeruleus (LC), which is the origin of the noradrenergic innervation of the preganglionic autonomic nuclei in the medulla oblongata [20].

Vagal afferent fibers arise from neurons in the nodose ganglia and their central and peripheral terminals are located respectively in the NTS and visceral organs. A number of NTS neurons directly, or indirectly via interneurons, connect with vagal motor neurons in the DMV, forming vago-vagal reflex, which may result in increased or decreased vagal efferent activity, and thus is an important component in the brainstem circuits controlling the vagal efferent function, independent of the higher brain [21-23].

Acetylcholine is the major transmitter of vagal preganglionic motoneurons in the DMV, which contains intense choline acetyltransferase (ChAT) [24]. By retrograde tracing of subdiaphrag- 
matic vagus, the majority (52\%) of labeled DMV cells is ChAT positive [25]. Nitric oxide (NO)synthesizing neurons are identified in the DMV as vagal motoneurons projecting to the GI tract and also in the NTS [26,27]. These neurons are involved in the gastric receptive relaxation reflex [26]. The catecholaminergic NTS neurons are tyrosine hydroxylase (TH) positive that relay the signals received by the NTS to other brain structures [28].

\subsubsection{The spinal intermediolateral cell column (IML) and the rostral ventrolateral medulla (RVLM)}

The sympathetic preganglionic motor neurons are located in the IML of the spinal cord. A group of brainstem neurons in the RVLM are sympathetic premotor neurons that project monosynaptically to the IML. Brainstem RVLM is the final common point of convergence of most brain pathways regulating sympathetic tone controlling functions of multisystemic visceral organs $[29,30]$. The efferent projections of the catecholamine neurons in the $\mathrm{C} 1$ area of the RVLM display important central control of the cardiovascular regulation [31]. Transneuronal labeling studies also showed that the RVLM is a major brain region involved in sympathetic control of the pancreas [32].

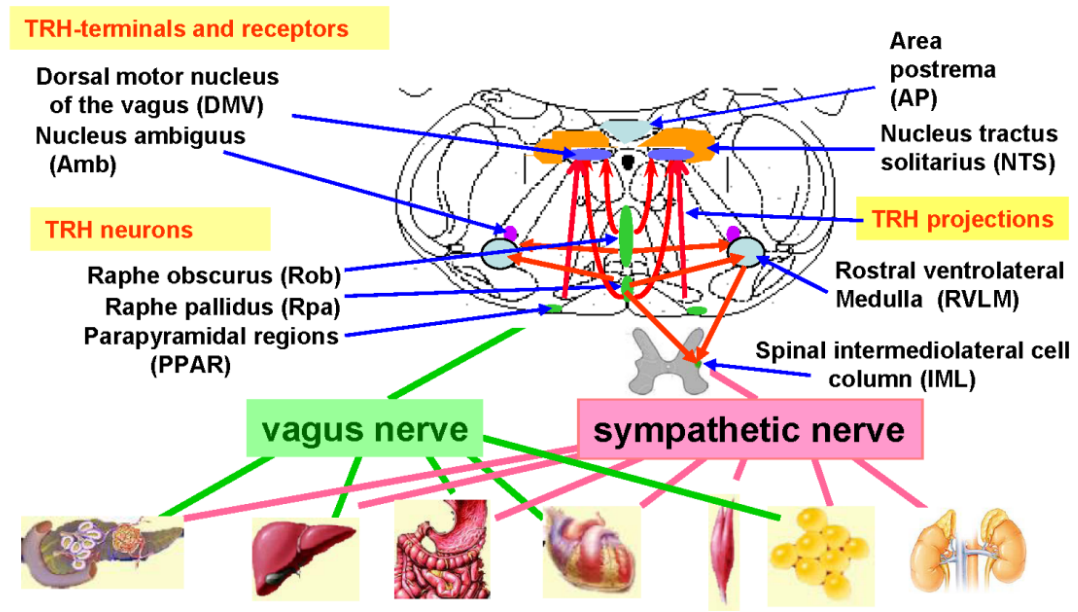

Figure 1. Coronal barainstem section (interaural-4.68 $\mathrm{mm}$ ) showing the location of THR neurons and THR terminals, and THR regulation of sympathovagal functions.

\section{2. sympathovagal-efferent regulation of pancreatic islet hormones secretion and food intake}

The autonomic nervous system plays a fundamental role in the brain regulation of metabolism, as this system innervates and tightly controls multisystemic organs involved in food intake and digestion, nutrition absorption, peripheral hormone secretion, blood circulation, and metabolic waste excretion. Here we focus on the pancreatic endocrine secretion and food intake. 


\subsubsection{Brain regulation of pancreatic endocrine secretion through vagal and sympathetic nerves}

The central nervous system requires glucose as an essential source of energy. To maintain blood glucose levels within a narrow range, the brain regulates pancreatic endocrine secretion through rich innervation of vagal and sympathetic nerves in the islets [33]. In rats, three of the five vagal branches, the posterior gastric, anterior gastric, and the hepatic branches, mediate insulin secretion [34]. The direct sympathetic innervation of the pancreas comes from the sympathetic chains and splanchnic and celiac ganglia [35]. Insulin secretion is stimulated by vagal activation and inhibited by sympathetic-adrenal activation [36]. The integrity of vaguscholinergic component plays an important role in pancreatic islet proliferation and insulin secretion of the cephalic phase and during the early absorption period, and is necessary to maintain normal glucose tolerance [33, 37-40]. Impairment in glucose tolerance is frequently observed in pancreas-transplanted patients due to denervation of the grafted pancreas. These patients have a high basal invariant insulin levels but a reduced insulin secretory capacity in response to glucose challenge; cephalic phase insulin release is absent [41-43]. Decreased $\beta$ cell mass was observed in dogs undergone pancreas-transplantation [44]. Acetylcholine is the major neurotransmitter of the vagus nervous and $\mathrm{M} 3$ receptor represents the major muscarinic receptor that is functional in pancreatic $\beta$-cells [36, 45, 46]. Mutant mice selectively lacking M3 receptor in pancreatic $\beta$-cells display impaired glucose tolerance and greatly reduced insulin release. In contrast, mice selectively overexpressing M3 receptors in $\beta$-cells show a profound increase in glucose tolerance and insulin release. Moreover, the $\beta$-cell M3-overexpressing mice are resistant to diet-induced glucose intolerance and hyperglycemia [47]. These findings indicate that autonomic nerves play a key role in maintaining proper insulin release and glucose homeostasis.

\subsubsection{The importance of the vagus nerve in food intake regulation}

Food intake provides body energy. Autonomic innervation, especially cholinergic processes of the vagus control hunger, meal initiation, and food digestion. Vagal-cholinergic (muscarinic) activation regulates gastric ghrelin biosynthesis and secretion [48, 49]. Elevation of plasma ghrelin induced by food deprivation can be blocked by subdiaphragmatic vagotomy and atropine treatment [50]. Circulating ghrelin levels in humans are increased or reduced by cholinergic agonists or antagonists, respectively [51].

\subsection{Brainstem sympathovagal-controlling circuits respond to metabolic alterations}

Hypoglycemia is a well established central stimulus that enhances autonomic activities [52-55]. The neuronal activations in the PVN, DVC and other autonomic-regulatory nuclei are initiated when blood glucose levels are immediately below the normal range; the extent of neuronal activation negatively correlates with glucose levels [55]. Microinjection of glucose into the DVC prevents hypoglycemia-induced gastric motility response, indicating a direct influence of glucose concentration on the DVC neurons $[56,57]$. Acute glucose deprivation by 2-deoxyglucose induces Fos expression in NADPH-positive neurons in the NTS and DMV [58] and in catecholamine neurons in the RVLM [59]. Electrophysiological data suggest that some DMV neurons have an enteroceptor function detecting changes in glucose concentration in their 
environment [60]; however, another study found that glucose had no direct effect on DMV neurons, which appear to be affected by glucose action on NTS neurons [61]. The NTS neurons transmit information of local glucose availability and peripheral glucose metabolic signals received from the vagal afferents toward other brain areas, such as the nearby DMV, via circuits mediating vagal-vagal reflex, and the hypothalamus, including the PVN, via the ascending adrenergic and noradrenergic pathways [61-64]. The response of medullary vagal-regulatory circuits to altered blood glucose levels seems independent of the higher brain structures. In dogs, decerebration and mid-brain or pontine section did not prevent insulin-hypoglycemiainduced gastric acid secretion, which was drastically reduced after destruction of the DMV [65]. Beside the enhanced vagal efferent outflow, which mediates hypoglycemia induced food intake, neuronal activation in the RVLM by glucose deprivation increases sympathetic efferent activity [59], which is important for the liver to produce and release more glucose. These findings indicate that activating brainstem autonomic regulatory circuits is an important counterregulatory response for changed metabolic status.

\section{Brainstem Thyrotropin-Releasing Hormone (TRH)-containing circuits regulate sympathovagal outflow to visceral organs}

\subsection{Brainstem TRH synthesizing neurons and their projections to the autonomic motor/ premotor nuclei}

TRH is a three amino acid neuropeptide originally discovered in the hypothalamic PVN, where it regulates pituitary thyrotropin release. Brainstem raphe nuclei, including the raphe pallidus (Rpa), raphe obscurus (Rob) and the parapyramidal regions (PPR) are among other major loci capable of TRH synthesis in the brain (Fig.1). Raphe nuclei project TRH-containing fibers to sympathetic and vagal motor neurons located respectively in the brainstem DVC, the RVLM, and the spinal IML, areas densely clustered with TRH-immunoreactive nerve terminals and TRH receptor 1 [66-69] (Figs.1,2). Electron microscopic studies revealed that TRH terminals make direct synaptic contacts with dendrites of neurons in medial NTS and vagal motoneurons throughout the DMV [68]. The direct effects of TRH are to excite DMV neurons and inhibit NTS neurons [70]. TRH-containing fibers also innervate sympathetic premotor loci, particularly the RVLM [69, 71, 72]. These TRH-containing brainstem-spinal circuits are important central components of autonomic regulation of visceral organ functions and in particular, the baroreflex pathways [73].

\subsection{Brainstem TRH regulation of gastric, pancreatic, and cardiovascular functions}

Studies in the 1980s by Amir S et al and others found that intracerebroventricular (icv) injection of TRH induces hyperglycemia through pathways involving the adrenal gland in rats, but prevents central and peripheral stimuli-induced hyperglycemia in mice through stimulating insulin release [74-78].

Our studies demonstrated that injection of TRH or its stable analog RX77368 into brain ventricles activates both sympathetic and vagal descending pathways, inducing sympatheti- 


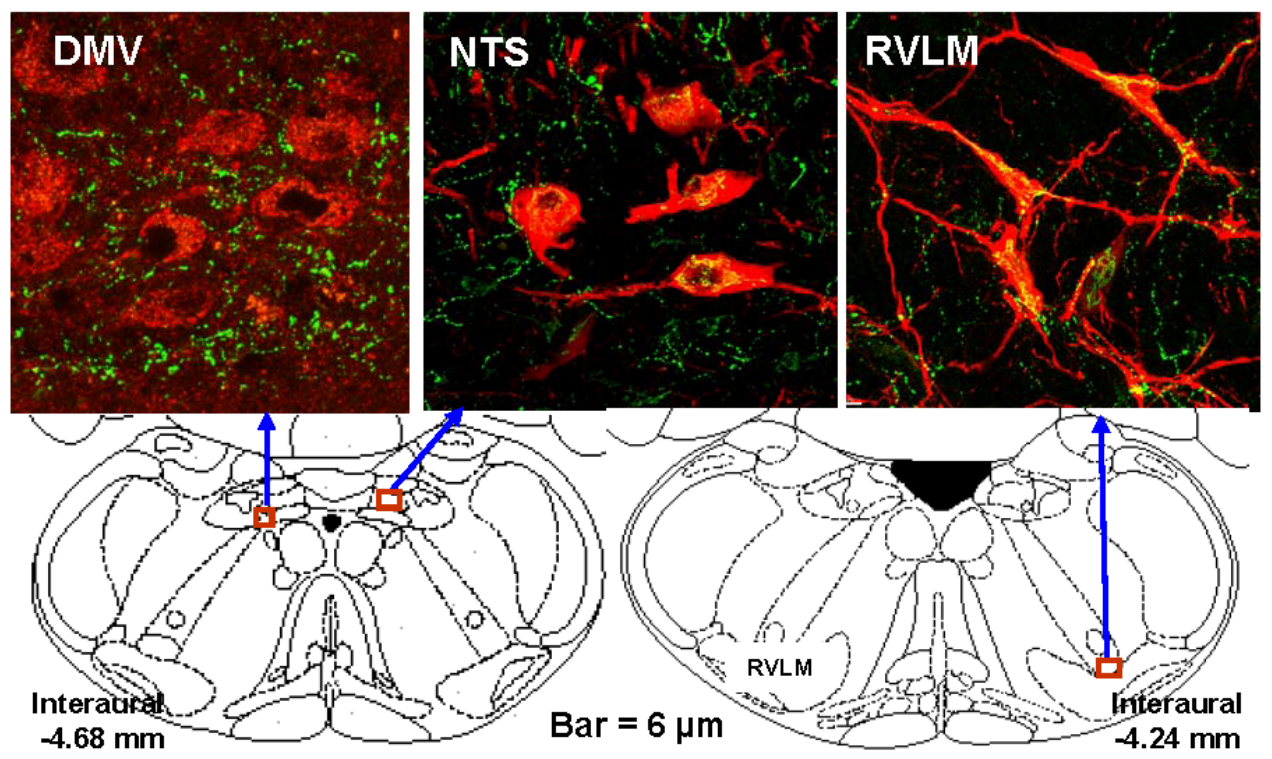

Figure 2. PreproTHR-containing fibres (green) and ChAT neurons (red) in the DMV and TH neurons (red) in the RLVM and NTS.

cally driven hyperglycemia, hypertension and tachycardia, and vagally mediated stimulation of gastric secretion/contractility, pancreatic insulin secretion, and ghrelin release [49, 69, 79-82]. The gastric myenteric plexus innervates smooth muscle and mucosal layers and receives dense and intricate network of vagal efferent axons [83-86]. Electrical stimulation of the rat cervical vagus nerve induces widespread Fos expression in the gastric myenteric plexus in rats [87, 88]. Similarly, intracisternal injection of TRH analog, known to activate vagal preganglionic neurons in the DMV and increase gastric vagal efferent discharges [80, 89,90], activates gastric myenteric neurons in rats [91]. Brainstem microinjection and intrathecal (it) injection studies revealed that pontine locus coeruleus, brainstem RVLM and spinal IML are TRH action sites for activating sympathetic efferent pathways [69, 79, 92, 93], whereas the DMV, the Amb, and the dorsal portion of the RVLM are among those responsible for the resulting stimulation of vagal efferent outflow [69, 94-96]. Substantial evidence shows that TRH is the only brain peptide fulfilling all of the criteria as a neurotransmitter and/or neuromodulator activating vagal motor neurons in the DMV [49, 69, 80, 82, 97]. TRH knockout mice are significantly hyperglycemic with impaired insulin secretion in response to glucose [98].

\subsection{Physiological and pathophysiological regulation of brainstem TRH gene expression}

Autonomic response to external and internal environmental changes is associated with activation of brainstem TRH containing pathways. Brainstem TRH gene expression is upregulated by energy deficiency or increased energy demand, such as starvation, hypothermia, and hypothyroidism $[49,99,100]$. 
The physiological role of brainstem TRH in regulating sympathovagal efferent activities responding to metabolic challenge was first evidenced in the animal model of cold exposure, which is wildly used to induce sympathetic-vagally mediated gastric ulceration [99, 101, 102]. Cold exposure activates not only TRH system in the hypothalamus but also TRH-containing Rpa/Rob/PPR-DVC pathways in the brainstem $[99,103]$. The hypothermia resulting from cold exposure induces Fos expression in the Rpa, Rob, PPR and DVC neurons and enhances brainstem TRH gene expression, especially in the Rpa and Rob [99, 104, 105]. These brainstem changes are with strongly concomitant activation of gastric myenteric neurons through the excitement of vagal-nicotinic pathways and therefore responsible for the vagal-mediated increases of gastric acid secretion/motility and sympathetic-mediated decrease of mucosal blood flow, leading to gastric ulcer formation [102, 106-108]. Cold exposure induced gastric ulceration and increased gastric emptying were prevented by icv injection of TRH antiserum or antisense oligodeoxynucleotides of TRH receptor, respectively [109, 110].

Brainstem TRH gene expression is influenced by thyroid hormone levels in a feedback regulatory manner. Thyroidectomy increases TRH mRNA levels in the raphe nuclei and the effect is reversed by thyroid hormone replacement [100]. This finding indicates that abnormal brainstem TRH gene expression and altered TRH regulation of sympathovagal efferent outflow may be involved in the autonomic disorders observed in hypo- or hyperthyroidism.

Our recent studies demonstrated that brainstem TRH is involved in food intake regulation. Intracisternal injection of the stable TRH analog RX77368 (7.5-25 ng) dose-dependently stimulated solid food intake by 2.4- to 3-fold in freely fed rats, an effect that lasted for 3 hours. By contrast, RX77368 at $25 \mathrm{ng}$ injected into the lateral ventricle induced a delayed and insignificant orexigenic effect only in the first hour. In pentobarbital-anesthetized rats, intracisternal injection of TRH analog (50 ng) induced a significant bi-peak increase in serum total ghrelin levels from the basal of $8.7 \pm 1.7 \mathrm{ng} / \mathrm{ml}$ to $13.4 \pm 2.4 \mathrm{ng} / \mathrm{ml}$ at $30 \mathrm{~min}$ and $14.5 \pm 2.0$ $\mathrm{ng} / \mathrm{ml}$ at $90 \mathrm{~min}$, which was prevented by either bilateral vagotomy (-60 $\mathrm{min}$ ) or atropine pretreatment $(2 \mathrm{mg} / \mathrm{kg},-30 \mathrm{~min})$ but magnified by bilateral adrenalectomy $(-60 \mathrm{~min})$. TRH analog induced food intake in freely fed rats was abolished by either peripheral atropine or ghrelin receptor antagonist (D-Lys-3)-GHRP-6 $(10 \mu \mathrm{mol} / \mathrm{kg})$, or intracisternal Y1 receptor antagonist 122PU91 $(10 \mathrm{nmol} / 5 \mu \mathrm{l})$. Brainstem TRH mRNA and TRH receptor1 mRNA increased by $57-58 \%$ and $33-35 \%$ in $24-48 \mathrm{~h}$ fasted rats and returned to the fed levels after a 3 hour re-feeding. Natural food intake in overnight fasted rats was significantly reduced by intracisternal TRH antibody, Y1 antagonist, and peripheral atropine. These data establish a physiological role of brainstem TRH in vagal-ghrelin-mediated stimulation of food intake, which involves interaction with brainstem Y1 receptors [49].

\subsection{Interaction of TRH with other neurotransmitters and neuropeptides in the DVC}

The TRH-synthesizing neurons in brainstem raphe nuclei contain other neuropeptides and neurotransmitters, such as substance $\mathrm{P}$ (SP) and serotonin (5-HT). These transmitters/peptides co-release with TRH in the raphe projections innervating the target autonomic-regulatory neurons. In the DVC, 5-HT potentiates and SP suppresses the vagal-activating action of TRH [111, 112]. 


\subsection{Upper GI afferent signals influence TRH regulation of vagal efferent activity}

The upper gut mechano-/chemo- signals and their impact on ascending sympathetic-vagal afferents are crucial information for the brain to adjust sympathetic-vagal efferent functions involved in controlling glucose and energy homeostasis [113, 114]. GI peptides, such as cholecystokinin (CCK) and secretin, released from the proximal small intestine, and peptide YY (PYY) and glucagon-like peptide-1 (GLP-1), released from the hindgut, all appear to accomplish their gastric/pancreatic regulatory functions through both the humoral route and the vagus nerve [113]. These peptides modulate, mostly inhibit, efferent vagal outflow at least partly through brainstem vago-vagal reflexive neurocircuits that initiated with stimulating vagal afferent pathways, acting on either vagal afferent terminals in the GI enteric plexuses, vagal afferent neurons in the nodose ganglions that express all the relevant receptors for these gut hormones, or brainstem AP/NTS neurons, where receptors of these peptides are localized $[113,114]$. Glucose itself is an activator of vagal afferents [114]. In addition, information of glucose metabolism in the liver is sent to the brainstem via the afferent fibers in the hepatic vagal branch. Sensors localized in the portal vein pass nutrition signals to the brain through sympathetic-spinal pathways [113, 114]. Of particular noticeable, the vagal-efferent activation by brainstem TRH is inhibited by these signals from proximal gut. We have found that intraduodenal infusion of lipid or intravenous infusion of glucose, CCK, secretin, or PYY inhibits intracisternal TRH-induced gastric acid secretion that is mediated by vagal efferent activation [115-117].

Collectively, research findings show that the TRH containing raphe-DVC pathways and rapheIML pathways play important physiological roles in maintaining metabolic homeostasis, through balancing sympathovagal outflow that controls multisystemic visceral organs.

\section{Sympathovagal imbalance is the linchpin of T2D pathophysiology}

Relative to healthy peers, diabetic patients have increased sympathetic and decreased parasympathetic activity that appears to be present at early stages of metabolic impairment, regardless of the presence or absence of autonomic neuropathy [118-121]. T2D patients have higher resting muscle sympathetic nerve activity burst incidence and arterial norepinephrine levels, lower plasma norepinephrine clearance and reduced neuronal reuptake, compared with obese metabolic syndrome patients [122]. The progression from obesity to T2D is associated with increased central sympathetic drive, blunted sympathetic responsiveness, and altered norepinephrine disposition [122]. Unbalanced autonomic function leads to the development of diabetes and its complications, including hypertension [123], increased risk of cardiovascular events such as arrhythmia [4, 124, 125], enhanced activity of hypothalamuspituitary-adrenal axis [126], potentiated hepatic glucose output [127], suppression of insulin release [128], insulin resistance [6], lipemia and increased visceral fat [129], chronic renal failure [130], reduced gastric secretion/motility and altered gut hormone secretion [131, 132]. Moreover, sympathetic overactivity may be a contributing factor to the development of T2D in nonobese men [133]. Vagal impairment contributes significantly to the predominance of sympathetic activity in T2D [4]. 


\subsection{The vagal regulation of visceral function is altered by abnormal blood glucose levels in T2D}

Converging evidence suggests that hyper- or hypoglycemia affects GI functions by influencing vagal-cholinergic outflow to the viscera. GI functions stimulated by vagal efferent activation, such as sham feeding-induced pancreatic polypeptide (PP) release and gastric acid secretion, were remarkably reduced in humans during hyperglycemia [134]. In the rat, experimental diabetes lowered gastric acid secretion, which did not decrease further after vagotomy [135]. Hyperglycemia induced by intravenous glucose infusion completely prevented the gastric acid secretion stimulated by intracisternal TRH analog [115]. In contrast to hyperglycemia, insulin-hypoglycemia induces central-vagal stimulus of upper GI functions and has been widely used to test vagus nerve integrity [136-139]. These findings establish the mediating role of the vagus nerve in GI functional alternations induced by altered glucose metabolism.

Gastroparesis is a common complication of diabetes [140]. Gastric acid secretion is markedly lower and gastric emptying abnormalities occur in about 30-50\% of diabetic patients [141-144]. Although morphological changes in the vagus nerve were identified in diabetic patients [145], many observations indicate that hyperglycemia itself may play a major role in the abnormal GI motility of T2D patients, in addition to the traditionally-attributed irreversible autonomic neuropathy $[143,146]$. Acute hyperglycemia causes reversible motility impairment in the GI tract in both healthy subjects and in diabetic patients and animals [147-151]. Delay in gastric emptying is observed within one week after streptozotocin treatment in rats, when there is no autonomic neuropathy developed [152]. Even changes in blood glucose levels within the normal postprandial range significantly impact gastric emptying in both normal subjects and diabetic patients [153]. These observations show that hyperglycemia in diabetes can influence vagal-mediated visceral functions through functional alteration, in addition to morphological damage, of the vagus nerve.

\subsection{Sympathovagal imbalance in T2D suppresses insulin secretory response to glucose}

T2D Patients frequently lose the first phase insulin release that is mainly triggered by vagal activation [154]. The vagal-mediated acute insulin response to glucose is absent in those with glucose levels above $115 \mathrm{mg} / \mathrm{dL}$ [155]. In fact, after intravenous glucose infusion, both the first and second phases of insulin secretion are impaired in T2D patients [156]. The impaired second phase insulin secretion may result from reduced incretin secretory response and the reduction of absolute incretin effect in T2D [156-158], both can be attributed to impaired vagal efferent activity [159]. The impaired vagal function reduces the proliferation of pancreatic islet $\beta$-cells, resulting in an approximately $60 \%$ reduction in $\beta$-cell mass in T2D patients $[38,160]$. With increasing duration of $\mathrm{T} 2 \mathrm{D}$, the decrease of postprandial insulin secretion becomes more prominent [161]. The contribution of sympathetic overactivity to the inhibition of insulin secretion in T2D was evidenced in a patient, who underwent a spinal-sympathetic blockage for treating a disorder that was not directly related to diabetes but resulted in a dramatic $50 \%$ decrease in her insulin need [162]. Adrenalectomy increases basal insulin secretion in rats [82]. 


\subsection{Sympathetic hyperactivity contributes to cardiovascular diseases in T2D}

Cardiovascular disease is the leading cause of mortality in patients with T2D. T2D patients have a high incidence of hypertension and nonischemic heart failure, and worse outcomes in acute cardiovascular events compared to non-diabetic controls [163, 164]. A key mechanism underlying cardiovascular disorders is an increase in sympathetic nerve activity [73, 165], in addition to pathological cardiovascular changes due to inflammation and over-activity of the renin-angiotensin system [164, 166-168], which are associated with altered sympathovagal function as well. The cardiac vagal and sympathetic nerve functions are both abnormal in T2D patients, but particularly shown as decreased cardiac vagal baroreflex sensitivity [169]. These autonomic dysregulation contribute to increased blood pressure (BP), cardiac arrhythmias and atrial fibrillation, and the resulting progression to heart failure [4, 118, 170-173]. The attenuated sympathetic response to hypotension may contribute directly to mortality in diabetes and cardiovascular disease [174]. Autonomic dysfunction has become one of the most powerful predictor of risk for cardiac mortality in T2D patients [169, 175].

\section{Brainstem TRH dysfunction is involved in the sympathovagal imbalance in T2D: Studies with T2D Goto-Kakizaki (GK) rats}

Our lab in the last 10 years used a T2D rat model and combined systemic T2D pathophysiology and autonomic neuroscience to assess the role of brainstem TRH in the central mechanism responsible for the sympathovagal imbalance in T2D.

\subsection{GK rat is a suitable animal model for studying sympathovagal imbalance in T2D}

The GK rat is an extensively studied polygenic model of non-obese T2D that was obtained by selective breeding of individuals with glucose intolerance from a non-diabetic Wistar rat colony [176,177]. GK rats are used to dissect genetic etiology of T2D [178,179], and exhibit wellcharacterized features typical of human T2D, such as fasting hyperglycemia, impaired insulinsecretory response to glucose, reduced $\beta$-cell mass, chronic inflammation, disruption of hepatic lipid metabolism, hypertension, and insulin resistance [97, 176, 178, 180, 181]. GK rats and human T2D share similar late complications, such as neuropathy, nephropathy, and cardiovascular disorders including heart failure [180, 182-184]. Glucose-stimulated insulin release was reduced by $90 \%$ in the first phase and by $75 \%$ in the second phase in GK rats [185]. Vagaldependent increase of islet blood flow, which is required for glucose-induced insulin secretion, is diminished in GK rats [186]. Carbachol, an agonist for muscarinic acetylcholine receptors, fully normalizes insulin secretion in GK rats responding to $16.7 \mathrm{mmol} / \mathrm{L}$ glucose through an effect abolished by atropine [187]. 


\subsection{Impaired brainstem TRH action on activating vagal efferents in T2D GK rats}

\subsubsection{Increased fat content and elevated serum leptin levels in T2D GK rats}

Higher amounts of visceral fat is a sign of a high ratio of sympathetic vs parasympathetic reactivity [129]. We measured the lean and fat body mass quantities in awake rats by noninvasive magnetic resonance imaging. Compared to Wistar rats with same body weight, GK rats have doubled fat mass and significantly less lean mass. During rat growth from $285 \mathrm{~g}$ to $320 \mathrm{~g}$, the increase in Wistar rats is mainly lean weight while that in GK rats is mainly fat weight. Coinciding with this finding, serum leptin levels elevated in GK rats in normally feed, fast, and refeed status. Hyperleptinemia is associated with increased sympathetic activity as leptin increases sympathetic nerve activity to influence cardiovascular, renal, muscle, endocrine, and adrenal gland functions [188, 189].

\subsubsection{Absence of vagally mediated gastric acid response to intracisternal TRH analog in T2D GK rats}

TRH is a physiological stimulator on DMV neurons to induce a vagally mediated excitation of gastric secretory/motility functions [80]. The well-known gastric acid-stimulatory effect of intracisternal injection of TRH analog was totally absent in T2D GK rats, indicating that TRH action in the DMV to activate vagal efferent outflow is severely damaged in GK rats.

5.2.3. Potentiated hyperglycemic and suppressed insulin early-phase responses to TRH analog injected intracisternally, intrathecally into the subarachnoid space at the thoracic 8-11 level, or microinjected into the RVLM in T2D GK rats

TRH analog RX77368 (50 ng) injected intracisternally induced markedly greater hyperglycemic and weaker insulin responses in GK rats than in Wistar rats. Bilateral vagotomy blocked RX77368-induced insulin secretion while adrenalectomy abolished its hyperglycemic effect. In adrenalectomized GK but not Wistar rats, RX77368 dramatically increased serum insulin levels by 6.5 -fold and decreased blood glucose levels from 154 to $98 \mathrm{mg} \%$; these changes were prevented by simultaneous vagotomy. These results indicate that central-vagal activation-induced insulin secretion is susceptible in T2D GK rats and the dominant sympatheticadrenal response to brainstem TRH plays a suppressing role on vagal-mediated insulin secretion. This unbalanced sympathovagal activation by medullary TRH may contribute to the impaired insulin secretion in T2D [82].

TRH analog RX77368 injected intrathecally or microinjected into the RVLM, the TRH action sites for activating the sympathetic efferent function, induced a significantly potentiated hyperglycemic response and an impaired first hour insulin response in T2D GK rats, compared to Wistar rats, indicating a sympathetic overactivation together with an impaired vagal counterregulatory response to hyperglycemia in GK rats [69, 82].

\subsubsection{Brainstem TRH-triggered cardioacceleration results in death from congestive heart failure in T2D} GK rats, showing diminished vagal efferent function in baroreceptor reflex

In comparison with Wistar rats, GK rats exhibited basal systolic hypertension $(152 \pm 2 \mathrm{mmHg})$ and a significantly potentiated, dose-related hypertensive response to intracisternal injection 
of TRH analog RX77368 (10-60 ng). In GK rats only, intracisternal RX77368 (30-60 ng) markedly increased heart rate $(+88 \mathrm{bpm})$ and induced acute cardiac mortality $(100 \%)$ resulting from congestive heart failure, concurrent with extreme hyperglycemia $(>480 \mathrm{mg} \%)$, increased plasma $\mathrm{H}_{2} \mathrm{O}_{2}$ and 8-isoprostane, and increased heart mRNA levels of NADPH oxidase 4 and vascular cell adhesion molecule-1, which are the oxidative stress and inflammation markers. GK rats also had elevated basal levels of plasma epinephrine, higher adrenal gene expression of epinephrine-synthesizing enzymes tyrosine hydroxylase and dopamine $\beta$-hydroxylase, and greater responses of plasma catecholamines and the adrenal enzymes to intracisternal TRH analog, compared to Wistar rats. Pretreatment with the nicotine receptor blocker hexamethonium prevented intracisternal TRH analog induced hypertensive and tachycardic responses, and cardiac mortality in GK rats. The $\alpha$-receptor blockage with phentolamine abolished the hypertensive response but enhanced tachycardia $(+160 \mathrm{bpm})$, and reduced mortality by $50 \%$. The angiotensin II type 1 receptor antagonist irbesartan prevented intracisternal RX77368induced increases in blood pressure, heart rate, and mortality. These findings indicate that sympathetic overactivation triggered by brainstem TRH and the lack of effective vagal counterregulation contribute to the cardiovascular morbidity and mortality in T2D, which involves heightened cardiac inflammation and peripheral oxidative stress responses to the sympathetic drive and a mediating role of renin-angiotensin system [97]. The cardiovascular autonomic imbalance in GK rats further confirms a diminished vagal-activating function of brainstem TRH, which is responsible for the damaged vagal arm function in the baroreceptor reflex.

\section{Summary and perspectives}

Using the T2D GK rat model, we found a damaged brainstem TRH action on activating the vagal efferent functions, which contributes to reveal the central mechanism of the sympathovagal imbalance in T2D. Further studies are warranted to investigate in the cellular and molecular levels of the abnormal vagal motor neuronal functions in $\mathrm{T} 2 \mathrm{D}$, such as insulin and TRH signaling in the DVC neurons.

\section{Author details}

Yang Hong*

Address all correspondence to: hoyang@ucla.edu.

Research \& Development, Department of Veterans Affairs, Greater Los Angeles Health Care System and Department of Medicine, David Geffen School of Medicine, University of California at Los Angeles and Los Angeles, California, USA 


\section{References}

[1] Seeley RJ and Tschop M. How diabetes went to our heads. Nat Med 2006; 12: 47-49.

[2] Schwartz MW and Porte DJ. Diabetes, obesity, and the brain. Science 2005; 307: 375-379.

[3] Oida E, Kannagi T, Moritani T and Yamori Y. Diabetic alteration of cardiac vagosympathetic modulation assessed with tone-entropy analysis. Acta Physiol Scand 1999; 165: 129-134.

[4] Perin PC, Maule S and Quadri R. Sympathetic nervous system, diabetes, and hypertension. Clin Exp Hypertens 2001; 23: 45-55.

[5] Huggett RJ, Scott EM, Gilbey SG, Stoker JB, Mackintosh AF and Mary DA. Impact of type 2 diabetes mellitus on sympathetic neural mechanisms in hypertension. Circulation 2003; 108: 3097-3101.

[6] Lindmark S, Wiklund U, Bjerle P and Eriksson JW. Does the autonomic nervous system play a role in the development of insulin resistance? A study on heart rate variability in first-degree relatives of Type 2 diabetes patients and control subjects. Diabet Med 2003; 20: 399-405.

[7] Grill HJ and Hayes MR. Hindbrain neurons as an essential hub in the neuroanatomically distributed control of energy balance. Cell Metab 2012; 16: 296-309.

[8] Grill HJ and Norgren R. Chronically decerebrate rats demonstrate satiation but not bait shyness. Science 1978: 201: 267-269.

[9] Grill HJ and Kaplan JM. Sham feeding in intact and chronic decerebrate rats. Am J Physiol 1992; 262: R1070-R1074.

[10] Harris RB, Kelso EW, Flatt WP, Bartness TJ and Grill HJ. Energy Expenditure and Body Composition of Chronically Maintained Decerebrate Rats in the Fed and Fasted Condition. Endocrinology 2006; 147: 1365-1376.

[11] Shapiro RE and Miselis RR. The central organization of the vagus nerve innervating the stomach of the rat. J Comp Neurol 1985; 238: 473-488.

[12] Pagani FD, Norman WP, Kasbekar DK and Gillis RA. Localization of sites within dorsal motor nucleus of vagus that affect gastric motility. Am J Physiol 1985; 249: G73-G84.

[13] Berthoud HR, Carlson NR and Powley TL. Topography of efferent vagal innervation of the rat gastrointestinal tract. Am J Physiol 1991; 260: R200-R207.

[14] Kalia M and Sullivan JM. Brainstem projections of sensory and motor components of the vagus nerve in the rat. J Comp Neurol 1982; 211: 248-265. 
[15] Gross PM, Wall KM, Pang JJ, Shaver SW and Wainman DS. Microvascular specializations promoting rapid interstitial solute dispersion in nucleus tractus solitarius. Am J Physiol 1990; 259: R1131-R1138.

[16] Kannan H and Yamashita H. Electrophysiological study of paraventricular nucleus neurons projecting to the dorsomedial medulla and their response to baroreceptor stimulation in rats. Brain Res 1983; 279: 31-40.

[17] Zhang X, Fogel R and Renehan WE. Stimulation of the paraventricular nucleus modulates the activity of gut-sensitive neurons in the vagal complex. Am J Physiol 1999; 277: G79-G90.

[18] Nishimura H and Oomura Y. Effects of hypothalamic stimulation on activity of dorsomedial medulla neurons that respond to subdiaphragmatic vagal stimulation. J Neurophysiol 1987; 58: 655-675.

[19] Ashford ML, Boden PR and Treherne JM. Tolbutamide excites rat glucoreceptive ventromedial hypothalamic neurones by indirect inhibition of ATP-K+ channels. Br J Pharmacol 1990; 101: 531-540.

[20] Ter Horst GJ, Toes GJ and Van WJD. Locus coeruleus projections to the dorsal motor vagus nucleus in the rat. Neuroscience 1991; 45: 153-160.

[21] Tougas G and Wang L. Pseudoaffective cardioautonomic responses to gastric distension in rats. Am J Physiol 1999; 277: R272-R278.

[22] Li Y, Hao Y, Zhu J and Owyang C. Serotonin released from intestinal enterochromaffin cells mediates luminal non-cholecystokinin-stimulated pancreatic secretion in rats. Gastroenterology 2000; 118: 1197-1207.

[23] McCann MJ and Rogers RC. Functional and Chemical Anatomy of a Gastric VagoVagal Reflex. In: Innervation of the Gut: Pathophysiological Implications, edited by Taché Y, Wingate D. and Burks TF. London: CRC Press, 1993.

[24] Oh JD, Woolf NJ, Roghani A, Edwards RH and Butcher LL. Cholinergic neurons in the rat central nervous system demonstrated by in situ hybridization of choline acetyltransferase mRNA. Neuroscience 1992; 47: 807-822.

[25] Sang Q and Young HM. The origin and development of the vagal and spinal innervation of the external muscle of the mouse esophagus. Brain Res 1998; 809: 253-268.

[26] Zheng ZL, Rogers RC and Travagli RA. Selective gastric projections of nitric oxide synthase-containing vagal brainstem neurons. Neuroscience 1999; 90: 685-694.

[27] Lin LH, Sahai AK, Rockland KS and Talman WT. The distribution of neuronal nitric oxide synthase in the nucleus tractus solitarii of the squirrel monkey. Brain Res 2000; 856: 84-92. 
[28] Dong YX, Xiong KH and Rao ZR. Medullary catecholaminergic neurons projecting to lateral hypothalamic area and expressing Fos after chemical stimulation of the stomach in the rat. J Hirnforsch 1997; 38: 3-7.

[29] Allen AM, O'Callaghan EL, Chen D and Bassi JK. Central Neural Regulation of Cardiovascular Function by Angiotensin: A Focus on the Rostral Ventrolateral Medulla. Neuroendocrinology 2009; 89:361-369.

[30] Oshima N, Kumagai H, Kawai A, Sakata K, Matsuura T and Saruta T. Three types of putative presympathetic neurons in the rostral ventrolateral medulla studied with rat brainstem-spinal cord preparation. Auton Neurosci 2000; 84: 40-49.

[31] Card JP, Sved JC, Craig B, Raizada M, Vazquez J and Sved AF. Efferent projections of rat rostroventrolateral medulla $\mathrm{C} 1$ catecholamine neurons: Implications for the central control of cardiovascular regulation. J Comp Neurol 2006; 499: 840-859.

[32] Jansen AS, Hoffman JL and Loewy AD. CNS sites involved in sympathetic and parasympathetic control of the pancreas: a viral tracing study. Brain Res 1997; 766: 29-38.

[33] Berthoud HR and Jeanrenaud B. Acute hyperinsulinemia and its reversal by vagotomy after lesions of the ventromedial hypothalamus in anesthetized rats. Endocrinology 1979; 105: 146-151.

[34] Berthoud HR, Fox EA and Powley TL. Localization of vagal preganglionics that stimulate insulin and glucagon secretion. Am J Physiol 1990; 258: R160-R168.

[35] Quinson N, Robbins HL, Clark MJ and Furness JB. Locations and innervation of cell bodies of sympathetic neurons projecting to the gastrointestinal tract in the rat. Arch Histol Cytol 2001; 64: 281-294.

[36] Ahren B. Autonomic regulation of islet hormone secretion--implications for health and disease. Diabetologia 2000; 43: 393-410.

[37] Trimble ER, Berthoud HR, Siegel EG, Jeanrenaud B and Renold AE. Importance of cholinergic innervation of the pancreas for glucose tolerance in the rat. Am J Physiol 1981; 241: E337-E341.

[38] Kiba T, Tanaka K, Numata K, Hoshino M, Misugi K and Inoue S. Ventromedial hypothalamic lesion-induced vagal hyperactivity stimulates rat pancreatic cell proliferation. Gastroenterology 1996; 110: 885-893.

[39] Kiba T. Relationships Between the Autonomic Nervous System and the Pancreas Including Regulation of Regeneration and Apoptosis: Recent Developments. Pancreas 2004; 29: E51-E58.

[40] Benthem L, Mundinger TO and Taborsky GJJ. Meal-induced insulin secretion in dogs is mediated by both branches of the autonomic nervous system. Am J Physiol Endocrinol Metab 2000; 278: E603-E610. 
[41] Secchi A, Caldara R, Caumo A, Monti LD, Bonfatti D, Di CV and Pozza G. Cephalicphase insulin and glucagon release in normal subjects and in patients receiving pancreas transplantation. Metabolism 1995; 44: 1153-1158.

[42] Smets YF, van der Pijl JW, Frolich M, Ringers J, de FJ and Lemkes HH. Insulin secretion and sensitivity after simultaneous pancreas-kidney transplantation estimated by continuous infusion of glucose with model assessment. Transplantation 2000; 69: 1322-1327.

[43] Christiansen E, Tibell A, Volund AA, Holst JJ, Rasmussen K, Schaffer L and Madsbad S. Metabolism of oral glucose in pancreas transplant recipients with normal and impaired glucose tolerance. J Clin Endocrinol Metab 1997; 82: 2299-2307.

[44] Earnhardt RC, Veldhuis JD, Cornett G and Hanks JB. Pathophysiology of hyperinsulinemia following pancreas transplantation: altered pulsatile versus Basal insulin secretion and the role of specific transplant anatomy in dogs. Ann Surg 2002; 236: 480-490.

[45] Henquin JC and Nenquin M. The muscarinic receptor subtype in mouse pancreatic B-cells. FEBS Lett 1988; 236: 89-92.

[46] Duttaroy A, Zimliki CL, Gautam D, Cui Y, Mears D and Wess J. Muscarinic stimulation of pancreatic insulin and glucagon release is abolished in $\mathrm{m} 3$ muscarinic acetylcholine receptor-deficient mice. Diabetes 2004; 53: 1714-1720.

[47] Gautam D, Han SJ, Hamdan FF, Jeon J, Li B, Li JH, Cui Y, Mears D, Lu H, Deng C, Heard T and Wess J. A critical role for beta cell M(3) muscarinic acetylcholine receptors in regulating insulin release and blood glucose homeostasis in vivo. Cell Metab 2006; 3: 449-461.

[48] Toshinai K, Mondal MS, Nakazato M, Date Y, Murakami N, Kojima M, Kangawa K and Matsukura S. Upregulation of Ghrelin expression in the stomach upon fasting, insulin-induced hypoglycemia, and leptin administration. Biochem Biophys Res Commun 2001; 281: 1220-1225.

[49] Ao Y, Go VL, Toy N, Li T, Wang Y, Song MK, Reeve JRJ, Liu Y and Yang H. Brainstem Thyrotropin-Releasing Hormone Regulates Food Intake through Vagal-Dependent Cholinergic Stimulation of Ghrelin Secretion. Endocrinology 2006; 147: 6004-6010.

[50] Williams DL, Grill HJ, Cummings DE and Kaplan JM. Vagotomy dissociates shortand long-term controls of circulating ghrelin. Endocrinology 2003; 144: 5184-5187.

[51] Broglio F, Gottero C, Van KP, Prodam F, Destefanis S, Benso A, Gauna C, Hofland L, Arvat E, Van Der Lely AJ and Ghigo E. Acetylcholine regulates ghrelin secretion in humans. J Clin Endocrinol Metab 2004; 89: 2429-2433. 
[52] Niimi M, Sato M, Tamaki M, Wada Y, Takahara J and Kawanishi K. Induction of Fos protein in the rat hypothalamus elicited by insulin- induced hypoglycemia. Neurosci Res 1995; 23: 361-364.

[53] Horn CC, Addis A and Friedman MI. Neural substrate for an integrated metabolic control of feeding behavior. Am J Physiol 1999; 276: R113-R119.

[54] Cai XJ, Evans ML, Lister CA, Leslie RA, Arch JR, Wilson S and Williams G. Hypoglycemia activates orexin neurons and selectively increases hypothalamic orexin-B levels: responses inhibited by feeding and possibly mediated by the nucleus of the solitary tract. Diabetes 2001; 50: 105-112.

[55] Yuan PQ and Yang H. Neuronal activation of brain vagal-regulatory pathways and upper gut enteric plexuses by insulin hypoglycemia. Am J Physiol Endocrinol Metab 2002; 283: E436-E448.

[56] Sakaguchi T, Aono T, Ohtake M and Sandoh N. Interaction of glucose signals between the nucleus of the vagus nerve and the portal vein area in the regulation of gastric motility in rats. Brain Res Bull 1994; 33: 469-471.

[57] Sakaguchi T and Nakadaira K. Interaction of glucose signals between the nucleus of the tractus solitarius and the portal vein area in the control of gastric acid secretion in rats. Brain Res 1991; 568: 299-302.

[58] Briski KP. Induction of Fos immunoreactivity by acute glucose deprivation in the rat caudal brainstem: relation to NADPH diaphorase localization [In Process Citation]. Histochem Cell Biol 1999; 111: 229-233.

[59] Ritter S, Llewellyn-Smith I and Dinh TT. Subgroups of hindbrain catecholamine neurons are selectively activated by 2-deoxy-D-glucose induced metabolic challenge. Brain Res 1998; 805: 41-54.

[60] Kobashi M and Adachi A. Effect of topical administration of glucose on neurons innervating abdominal viscera in dorsal motor nucleus of vagus in rats. Jpn J Physiol 1994; 44: 729-734.

[61] Ferreira MJ, Browning KN, Sahibzada N, Verbalis JG, Gillis RA and Travagli RA. Glucose effects on gastric motility and tone evoked from the rat dorsal vagal complex. J Physiol 2001; 536: 141-152.

[62] Niijima A. Glucose-sensitive afferent nerve fibres in the hepatic branch of the vagus nerve in the guinea-pig. J Physiol 1982; 332: 315-323.

[63] Yettefti K, Orsini JC and Perrin J. Characteristics of glycemia-sensitive neurons in the nucleus tractus solitarii: possible involvement in nutritional regulation. Physiol Behav 1997; 61: 93-100. 
[64] Cunningham ETJ, Bohn MC and Sawchenko PE. Organization of adrenergic inputs to the paraventricular and supraoptic nuclei of the hypothalamus in the rat. J Comp Neurol 1990; 292: 651-667.

[65] Kerr FW and Preshaw RM. Secretomotor function of the dorsal motor nucleus of the vagus. J Physiol 1969; 205: 405-415.

[66] Lynn RB, Kreider MS and Miselis RR. Thyrotropin-releasing hormone-immunoreactive projections to the dorsal motor nucleus and the nucleus of the solitary tract of the rat. J Comp Neurol 1991; 311: 271-288.

[67] Sasek CA, Wessendorf MW and Helke CJ. Evidence for co-existence of thyrotropinreleasing hormone, substance $\mathrm{P}$ and serotonin in ventral medullary neurons that project to the intermediolateral cell column in the rat. Neuroscience 1990; 35: 105-119.

[68] Rinaman L, Miselis RR and Kreider MS. Ultrastructural localization of thyrotropinreleasing hormone immunoreactivity in the dorsal vagal complex in rat. Neurosci Lett 1989; 104: 7-12.

[69] Ao Y, Ko M, Chen A, Marvizon JC, Adelson D, Song MK, Go VL, Liu YY and Yang $\mathrm{H}$. Potent hyperglycemic and hyperinsulinemic effects of thyrotropin-releasing hormone microinjected into the rostroventrolateral medulla and abnormal responses in type 2 diabetic rats. Neuroscience 2010; 169: 706-719.

[70] McCann MJ, Hermann GE and Rogers RC. Thyrotropin-releasing hormone: effects on identified neurons of the dorsal vagal complex. J Auton Nerv Syst 1989; 26: 107-112.

[71] Underwood MD, Iadecola C and Reis DJ. Lesions of the rostral ventrolateral medulla reduce the cerebrovascular response to hypoxia. Brain Res 1994; 635: 217-223.

[72] Ross CA, Ruggiero DA, Park DH, Joh TH, Sved AF, Fernandez-Pardal J, Saavedra JM and Reis DJ. Tonic vasomotor control by the rostral ventrolateral medulla: effect of electrical or chemical stimulation of the area containing $\mathrm{C} 1$ adrenaline neurons on arterial pressure, heart rate, and plasma catecholamines and vasopressin. J Neurosci 1984; 4: 474-494.

[73] Malpas SC. Sympathetic nervous system overactivity and its role in the development of cardiovascular disease. Physiol Rev 2010; 90: 513-557.

[74] Marubashi S, Kunii Y, Tominaga M and Sasaki H. Modulation of plasma glucose levels by thyrotropin-releasing hormone administered intracerebroventricularly in the rat. Neuroendocrinology 48: 640-644, 1988.

[75] Amir S and Rivkind AI. Prevention of clonidine-stimulated hyperglycemia by thyrotropin-releasing hormone. Peptides 1988; 9: 527-531.

[76] Amir S, Harel M and Rivkind AI. Thyrotropin-releasing hormone potently reverses epinephrine-stimulated hyperglycemia in mice. Brain Res 1987; 435: 112-122. 
[77] Amir S and Jackson IM. Immunological blockade of endogenous thyrotropin-releasing hormone impairs recovery from hyperglycemia in mice. Brain Res 1988; 462: 160-162.

[78] Amir S and Butler PD. Thyrotropin-releasing hormone blocks neurally-mediated hyperglycemia through central action. Peptides 1988; 9: 31-35.

[79] Paakkari I, Siren AL, Nurminen ML and Svartstrom-Fraser M. Injection of thyrotropin releasing hormone into the locus coeruleus increases blood pressure. Eur Heart J 1987; 8 Suppl B: 147-151.

[80] Taché $\mathrm{Y}$ and Yang H. Role of medullary TRH in the vagal regulation of gastric function. In: Innervation of the Gut: Pathophysiological Implications, edited by Wingate DL and Butkd TF. Boca Raton: CRC, 1994.

[81] Yang H, Tache Y, Ohning G and Go VL. Activation of raphe pallidus neurons increases insulin through medullary thyrotropin-releasing hormone (TRH)-vagal pathways. Pancreas 2002; 25: 301-307.

[82] Ao Y, Toy N, Song MK, Go VL and Yang H. Altered glucose and insulin responses to brain medullary thyrotropin-releasing hormone (TRH)-induced autonomic activation in type 2 diabetic Goto-Kakizaki rats. Endocrinology 2005; 146: 5425-5432.

[83] Furness JB, Lloyd KC, Sternini C and Walsh JH. Evidence that myenteric neurons of the gastric corpus project to both the mucosa and the external muscle: myectomy operations on the canine stomach. Cell Tissue Res 1991; 266: 475-481.

[84] Pfannkuche H, Reiche D, Sann H and Schemann M. Different subpopulations of cholinergic and nitrergic myenteric neurones project to mucosa and circular muscle of the guinea-pig gastric fundus. Cell Tissue Res 1998; 292: 463-475.

[85] Holst MC, Kelly JB and Powley TL. Vagal preganglionic projections to the enteric nervous system characterized with Phaseolus vulgaris-leucoagglutinin. J Comp Neurol 1997; 381: 81-100.

[86] Berthoud HR. Anatomical demonstration of vagal input to nicotinamide acetamide dinucleotide phosphate diaphorase-positive (nitrergic) neurons in rat fundic stomach. J Comp Neurol 1995; 358: 428-439.

[87] Zheng $\mathrm{H}$ and Berthoud HR. Functional vagal input to gastric myenteric plexus as assessed by vagal stimulation-induced Fos expression. Am J Physiol Gastrointest Liver Physiol 2000; 279: G73-G81.

[88] Zheng H, Lauve A, Patterson LM and Berthoud HR. Limited excitatory local effector function of gastric vagal afferent intraganglionic terminals in rats. Am J Physiol 1997; 273: G661-G669. 
[89] Berthoud HR, Patterson LM and Zheng H. Vagal-enteric interface: Vagal activationinduced expression of c-Fos and p-CREB in neurons of the upper gastrointestinal tract and pancreas. Anat Rec 2001; 262: 29-40.

[90] O-Lee TJ, Wei JY and Taché Y. Intracisternal TRH and RX 77368 potently activate gastric vagal efferent discharge in rats. Peptides 1997; 18: 213-219.

[91] Miampamba M, Yang H, Sharkey KA and Tache Y. Intracisternal TRH analog induces Fos expression in gastric myenteric neurons and glia in conscious rats. Am J Physiol Gastrointest Liver Physiol 2001; 280: G979-G991.

[92] Assadian H, Ishikawa Y, Shimatsu A, Tanoh T and Imura H. Serotoninergic denervation suppresses the sympathetic outflow induced by thyrotropin-releasing hormone in conscious rats. J Auton Nerv Syst 1991; 35: 193-198.

[93] Ishikawa Y, Shimatsu A, Kato Y, Murakami Y and Imura H. Effects of intrathecal administration of thyrotropin releasing hormone and its analogue, DN1417, on plasma glucose and catecholamine levels in conscious rats. Brain Res 1990; 514: 1-4.

[94] Ishikawa T, Yang H and Taché Y. Medullary sites of action of the TRH analogue, RX 77368, for stimulation of gastric acid secretion in the rat. Gastroenterology 1988; 95: 1470-1476.

[95] Stephens RL, Ishikawa T, Weiner H, Novin D and Taché Y. TRH analogue, RX 77368, injected into dorsal vagal complex stimulates gastric secretion in rats. Am J Physiol 1988 254: G639-G643.

[96] Yoneda S, Kadowaki M, Kuramoto H, Fukui H and Takaki M. Enhanced colonic peristalsis by impairment of nitrergic enteric neurons in spontaneously diabetic rats. Auton Neurosci 2001; 92: 65-71.

[97] Yang H, Nyby MD, Ao Y, Chen A, Adelson DW, Smutko V, Wijesuriya J, Go VL and Tuck ML. Role of brainstem thyrotropin-releasing hormone-triggered sympathetic overactivation in cardiovascular mortality in type 2 diabetic Goto-Kakizaki rats. Hypertens Res 2012; 35: 157-165.

[98] Yamada M, Saga Y, Shibusawa N, Hirato J, Murakami M, Iwasaki T, Hashimoto K, Satoh T, Wakabayashi K, Taketo MM and Mori M. Tertiary hypothyroidism and hyperglycemia in mice with targeted disruption of the thyrotropin-releasing hormone gene. Proc Natl Acad Sci U S A 1997; 94: 10862-10867.

[99] Yang H, Wu SV, Ishikawa T and Taché Y. Cold exposure elevates thyrotropin-releasing hormone gene expression in medullary raphe nuclei: relationship with vagally mediated gastric erosions. Neuroscience 1994; 61: 655-663.

[100] Yang H, Yuan P, Wu V and Tache Y. Feedback regulation of thyrotropin-releasing hormone gene expression by thyroid hormone in the caudal raphe nuclei in rats. Endocrinology 1999; 140: 43-49. 
[101] Arai I, Muramatsu M and Aihara H. Body temperature dependent decrease of gastric blood flow in restraint and water-immersion stressed rats. J Pharmacobiodyn 1986; 9: 678-682.

[102] Arai I, Muramatsu M and Aihara H. Body temperature dependency of gastric regional blood flow, acid secretion and ulcer formation in restraint and water-immersion stressed rats. Jpn J Pharmacol 1986; 40: 501-504.

[103] Zoeller RT, Kabeer N and Albers HE. Cold exposure elevates cellular levels of messenger ribonucleic acid encoding thyrotropin-releasing hormone in paraventricular nucleus despite elevated levels of thyroid hormones. Endocrinology 1990; 127: 2955-2962.

[104] Bonaz B and Taché Y. Induction of Fos immunoreactivity in the rat brain after coldrestraint induced gastric lesions and fecal excretion. Brain Res 1994; 652: 56-64.

[105] Yang H, Yuan PQ, Wang L and Taché Y. Activation of the parapyramidal region in the ventral medulla stimulates gastric acid secretion through vagal pathways in rats. Neuroscience 95: 773-779, 2000.

[106] Yuan PQ, Tache Y, Miampamba M and Yang H. Acute cold exposure induces vagally mediated Fos expression in gastric myenteric neurons in conscious rats. Am J Physiol Gastrointest Liver Physiol 2001; 281: G560-G568.

[107] Hayase M and Takeuchi K. Gastric acid secretion and lesion formation in rats under water- immersion stress. Dig Dis Sci 1986; 31: 166-171.

[108] Witty RT and Long JF. Effect of ambient temperature on gastric secretion and food intake in the rat. Am J Physiol 1970; 219: 1359-1362.

[109] Basso N, Bagarani M, Pekary AE, Genco A and Materia A. Role of thyrotropin-releasing hormone in stress ulcer formation in the rat. Dig Dis Sci 1988; 33: 819-823.

[110] Martinez V, Wang L and Tache Y. Central TRH receptor 1 antisense blocks cold-induced gastric emptying but not brain c-Fos induction. Peptides 2001; 22: 81-90.

[111] Yang H and Taché Y. Substance P in the dorsal vagal complex inhibits medullary TRH-induced gastric acid secretion in rats. Am J Physiol 1997; 272: G987-G993.

[112] Yoneda M and Taché Y. Serotonin enhances gastric acid response to TRH analogue in dorsal vagal complex through 5-HT2 receptors in rats. Am J Physiol 1995; 269: R1R6.

[113] Berthoud HR. Vagal and hormonal gut-brain communication: from satiation to satisfaction. Neurogastroenterol Motil 2008; 20 Suppl 1: 64-72.

[114] Thorens B and Larsen PJ. Gut-derived signaling molecules and vagal afferents in the control of glucose and energy homeostasis. Curr Opin Clin Nutr Metab Care 2004; 7: 471-478. 
[115] Doong ML and Yang H. Intravenous glucose infusion decreases intracisternal thyrotropin-releasing hormone induced vagal stimulation of gastric acid secretion in anesthetized rats. Neurosci Lett 2003; 340: 49-52.

[116] Yang H. Central and peripheral regulation of gastric acid secretion by peptide YY. Peptides 2002; 23: 349-358.

[117] Yang H, Kawakubo K, Wong H, Ohning G, Walsh J and Tache Y. Peripheral PYY inhibits intracisternal TRH-induced gastric acid secretion by acting in the brain. Am J Physiol Gastrointest Liver Physiol 2000; 279: G575-G581.

[118] Urbancic-Rovan V, Meglic B, Stefanovska A, Bernjak A, Azman-Juvan K and Kocijancic A. Incipient cardiovascular autonomic imbalance revealed by wavelet analysis of heart rate variability in Type 2 diabetic patients. Diabet Med 2007; 24: 18-26.

[119] Carnethon MR, Jacobs DRJ, Sidney S and Liu K. Influence of autonomic nervous system dysfunction on the development of type 2 diabetes: the CARDIA study. Diabetes Care 2003; 26: 3035-3041.

[120] Frontoni S. Comment on: Straznicky et al. neuroadrenergic dysfunction along the diabetes continuum: a comparative study in obese metabolic syndrome subjects. Diabetes 2012;61:2506-2516. Diabetes 2013; 62: e1.

[121] Straznicky NE, Lambert EA and Lambert GW. Response to Comment on: Straznicky et al. neuroadrenergic dysfunction along the diabetes continuum: a comparative study in obese metabolic syndrome subjects. Diabetes 2012;61:2506-2516. Diabetes 2013; 62: e2.

[122] Straznicky NE, Grima MT, Sari CI, Eikelis N, Lambert EA, Nestel PJ, Esler MD, Dixon JB, Chopra R, Tilbrook AJ, Schlaich MP and Lambert GW. Neuroadrenergic dysfunction along the diabetes continuum: a comparative study in obese metabolic syndrome subjects. Diabetes 2012; 61: 2506-2516.

[123] Frontoni S, Bracaglia D and Gigli F. Relationship between autonomic dysfunction, insulin resistance and hypertension, in diabetes. Nutr Metab Cardiovasc Dis 2005; 15: 441-449.

[124] Mori A, Maruyama T, Ohashi N, Shibuya T, Sakai K, Tatebe H, Inoue H, Kato T and Okuno M. Impaired autonomic function in type 2 diabetic patients during upper gastrointestinal endoscopy. J Gastroenterol 2008; 43: 603-608.

[125] Manzella D and Paolisso G. Cardiac autonomic activity and Type II diabetes mellitus. Clin Sci (Lond ) 2005; 108: 93-99.

[126] Chiodini I, Di LS, Morelli V, Epaminonda P, Coletti F, Masserini B, Scillitani A, Arosio $\mathrm{M}$ and Adda G. Hypothalamic-pituitary-adrenal activity in type 2 diabetes mellitus: role of autonomic imbalance. Metabolism 2006; 55: 1135-1140.

[127] Dicostanzo CA, Dardevet DP, Neal DW, Lautz M, Allen E, Snead W and Cherrington $\mathrm{AD}$. Role of the hepatic sympathetic nerves in the regulation of net hepatic glucose 
uptake and the mediation of the portal glucose signal. Am J Physiol Endocrinol Metab 2006; 290: E9-E16.

[128] Hu X, Friedman D, Hill S, Caprioli R, Nicholson W, Powers AC, Hunter L and Limbird LE. Proteomic exploration of pancreatic islets in mice null for the alpha2A adrenergic receptor. J Mol Endocrinol 2005; 35: 73-88.

[129] Lindmark S, Lonn L, Wiklund U, Tufvesson M, Olsson T and Eriksson JW. Dysregulation of the autonomic nervous system can be a link between visceral adiposity and insulin resistance. Obes Res 2005; 13: 717-728.

[130] Schlaich MP, Socratous F, Hennebry S, Eikelis N, Lambert EA, Straznicky N, Esler MD and Lambert GW. Sympathetic Activation in Chronic Renal Failure. J Am Soc Nephrol 2009; 20:933-939.

[131] el-Salhy M. Neuroendocrine peptides of the gastrointestinal tract of an animal model of human type 2 diabetes mellitus. Acta Diabetol 1998; 35: 194-198.

[132] Kashyap P and Farrugia G. Diabetic gastroparesis: what we have learned and had to unlearn in the past 5 years. Gut 2010; 59: 1716-1726.

[133] Grantham NM, Magliano DJ, Tanamas SK, Soderberg S, Schlaich MP and Shaw JE. Higher heart rate increases risk of diabetes among men: The Australian Diabetes Obesity and Lifestyle (AusDiab) Study. Diabet Med 2013; 30:421-427.

[134] Lam WF, Masclee AA, De Boer SY and Lamers CB. Hyperglycemia reduces gastric secretory and plasma pancreatic polypeptide responses to modified sham feeding in humans. Digestion 1993; 54: 48-53.

[135] Mehta N, Veliath S and Thombre DP. The effect of bilateral gastric vagotomy and histamine stimulation on parietal cell activity in streptozotocin induced diabetic rat model. Indian J Physiol Pharmacol 1993; 37: 30-34.

[136] Vu MK, Straathof JW, Schaar PJ, Arndt JW, Ringers J, Lamers CB and Masclee AA. Motor and sensory function of the proximal stomach in reflux disease and after laparoscopic Nissen fundoplication. Am J Gastroenterol 1999; 94: 1481-1489.

[137] Nilsell K and Ewerth S. The acid secretory response to betazole and insulin hypoglycemia after selective proximal vagotomy for duodenal ulcer. Acta Chir Scand 1981; 147: 431-434.

[138] Stenquist B. Studies on vagal activation of gastric acid secretion in man. Acta Physiol Scand Suppl 1979; 465: 1-31.

[139] Smith RB, Edwards JP and Johnston D. Effect of vagotomy on exocrine pancreatic and biliary secretion in man. Am J Surg 1981; 141: 40-47.

[140] Quigley EM. The pathophysiology of diabetic gastroenteropathy: more vague than vagal [editorial; comment]. Gastroenterology 1997; 113: 1790-1794. 
[141] Horowitz M, Harding PE, Maddox A and et al. Gastric and oesophageal emptying in insulin-dependent diabetes mellitus. J Gastroenterol Hepatol 1986; 1: 97.

[142] Horowitz M, Harding PE, Maddox AF, Wishart JM, Akkermans LM, Chatterton BE and Shearman DJ. Gastric and oesophageal emptying in patients with type 2 (noninsulin- dependent) diabetes mellitus. Diabetologia 32: 151-159, 1989.

[143] Kong MF and Horowitz M. Gastric emptying in diabetes mellitus: relationship to blood-glucose control. Clin Geriatr Med 1999; 15: 321-338.

[144] Nakamura T, Takebe K, Imamura K, Miyazawa T, Ishii M, Kudoh K, Terada A, Machida K, Kikuchi H and Kasai F. Decreased gastric secretory functions in diabetic patients with autonomic neuropathy. Tohoku J Exp Med 1994; 173: 199-208.

[145] Britland ST, Young RJ, Sharma AK, Lee D, Ah-See AK and Clarke BF. Vagus nerve morphology in diabetic gastropathy. Diabet Med 1990; 7: 780-787.

[146] Fraser R, Horowitz M and Dent J. Hyperglycaemia stimulates pyloric motility in normal subjects. Gut 1991; 32: 475-478.

[147] Fraser RJ, Horowitz M, Maddox AF, Harding PE, Chatterton BE and Dent J. Hyperglycaemia slows gastric emptying in type 1 (insulin-dependent) diabetes mellitus. Diabetologia 1990; 33: 675-680.

[148] Bjornsson ES, Urbanavicius V, Eliasson B, Attvall S, Smith U and Abrahamsson H. Effects of hyperglycemia on interdigestive gastrointestinal motility in humans. Scand J Gastroenterol 1994; 29: 1096-1104.

[149] Morgan LM, Tredger JA, Hampton SM, French AP, Peake JC and Marks V. The effect of dietary modification and hyperglycaemia on gastric emptying and gastric inhibitory polypeptide (GIP) secretion. Br J Nutr 1988; 60: 29-37.

[150] Barnett JL and Owyang C. Serum glucose concentration as a modulator of interdigestive gastric motility. Gastroenterology 1988; 94: 739-744.

[151] Chang FY, Lee SD, Yeh GH and Wang PS. Influence of blood glucose levels on rat liquid gastric emptying. Dig Dis Sci 1996; 41: 528-532.

[152] Yamano M, Kamato T, Nagakura Y and Miyata K. Effects of gastroprokinetic agents on gastroparesis in streptozotocin-induced diabetic rats. Naunyn Schmiedebergs Arch Pharmacol 1997; 356: 145-150.

[153] Schvarcz E, Palmer M, Aman J, Horowitz M, Stridsberg M and Berne C. Physiological hyperglycemia slows gastric emptying in normal subjects and patients with insulin-dependent diabetes mellitus. Gastroenterology 1997; 113: 60-66.

[154] Gallwitz B, Kazda C, Kraus P, Nicolay C and Schernthaner G. Contribution of insulin deficiency and insulin resistance to the development of type 2 diabetes: nature of early stage diabetes. Acta Diabetol 2013; 50: 39-45. 
[155] Brunzell JD, Robertson RP, Lerner RL, Hazzard WR, Ensinck JW, Bierman EL and Porte DJ. Relationships between fasting plasma glucose levels and insulin secretion during intravenous glucose tolerance tests. J Clin Endocrinol Metab 1976; 42: 222-229.

[156] Woerle HJ, Carneiro L, Derani A, Goke B and Schirra J. The role of endogenous incretin secretion as amplifier of glucose-stimulated insulin secretion in healthy subjects and patients with type 2 diabetes. Diabetes 2012; 61: 2349-2358.

[157] Vollmer K, Gardiwal H, Menge BA, Goetze O, Deacon CF, Schmidt WE, Holst JJ and Meier JJ. Hyperglycemia acutely lowers the postprandial excursions of glucagon-like Peptide-1 and gastric inhibitory polypeptide in humans. J Clin Endocrinol Metab 2009; 94: 1379-1385.

[158] Knop FK, Aaboe K, Vilsboll T, Volund A, Holst JJ, Krarup T and Madsbad S. Impaired incretin effect and fasting hyperglucagonaemia characterizing type 2 diabetic subjects are early signs of dysmetabolism in obesity. Diabetes Obes Metab 2012; 14: 500-510.

[159] Rocca AS and Brubaker PL. Role of the vagus nerve in mediating proximal nutrientinduced glucagon-like peptide-1 secretion. Endocrinology 1999; 140: 1687-1694.

[160] Butler AE, Campbell-Thompson M, Gurlo T, Dawson DW, Atkinson M and Butler PC. Marked Expansion of Exocrine and Endocrine Pancreas with Incretin Therapy in Humans with increased Exocrine Pancreas Dysplasia and the potential for Glucagonproducing Neuroendocrine Tumors. Diabetes 2013.

[161] Shim WS, Kim SK, Kim HJ, Kang ES, Ahn CW, Lim SK, Lee HC and Cha BS. Decrement of postprandial insulin secretion determines the progressive nature of type-2 diabetes. Eur J Endocrinol 2006; 155: 615-622.

[162] Kapural L, Hayek SM, Stanton-Hicks M and Mekhail N. Decreased insulin requirements with spinal cord stimulation in a patient with diabetes. Anesth Analg 2004; 98: 745-746.

[163] Kannel WB and McGee DL. Diabetes and cardiovascular disease. The Framingham study. JAMA 1979; 241: 2035-2038.

[164] Lockhart CJ, Hamilton PK, McVeigh KA and McVeigh GE. A cardiologist view of vascular disease in diabetes. Diabetes Obes Metab 2008; 10: 279-292.

[165] Palatini P and Julius S. The role of cardiac autonomic function in hypertension and cardiovascular disease. Curr Hypertens Rep 2009; 11: 199-205.

[166] Taegtmeyer H, Golfman L, Sharma S, Razeghi P and van AM. Linking gene expression to function: metabolic flexibility in the normal and diseased heart. Ann N Y Acad Sci 2004; 1015: 202-213.

[167] Boudina S and Abel ED. Diabetic cardiomyopathy revisited. Circulation 2007; 115: 3213-3223. 
[168] Guha A, Harmancey R and Taegtmeyer H. Nonischemic heart failure in diabetes mellitus. Curr Opin Cardiol 2008; 23: 241-248.

[169] Paolillo S, Rengo G, Pagano G, Pellegrino T, Savarese G, Femminella GD, Tuccillo M, Boemio A, Attena E, Formisano R, Petraglia L, Scopacasa F, Galasso G, Leosco D, Trimarco B, Cuocolo A and Perrone-Filardi P. Impact of Diabetes Mellitus on Cardiac Sympathetic Innervation in Patients With Heart Failure: A 123I meta-iodobenzylguanidine (123IMIBG) scintigraphic study. Diabetes Care 2013.

[170] Aso Y, Wakabayashi S, Nakano T, Yamamoto R, Takebayashi K and Inukai T. High serum high-sensitivity $\mathrm{C}$-reactive protein concentrations are associated with relative cardiac sympathetic overactivity during the early morning period in type 2 diabetic patients with metabolic syndrome. Metabolism 2006; 55: 1014-1021.

[171] Dublin S, Glazer NL, Smith NL, Psaty BM, Lumley T, Wiggins KL, Page RL and Heckbert SR. Diabetes mellitus, glycemic control, and risk of atrial fibrillation. J Gen Intern Med 2010; 25: 853-858.

[172] Esler M. Sympathetic nervous activation in essential hypertension: commonly neglected as a therapeutic target, usually ignored as a drug side effect. Hypertension 2010; 55: 1090-1091.

[173] Voulgari C, Papadogiannis D and Tentolouris N. Diabetic cardiomyopathy: from the pathophysiology of the cardiac myocytes to current diagnosis and management strategies. Vasc Health Risk Manag 2010; 6: 883-903.

[174] Adler GK, Bonyhay I, Failing H, Waring E, Dotson S and Freeman R. Antecedent hypoglycemia impairs autonomic cardiovascular function: implications for rigorous glycemic control. Diabetes 58: 360-366, 2009.

[175] Vinik AI and Erbas T. Cardiovascular autonomic neuropathy: diagnosis and management. Curr Diab Rep 2006; 6: 424-430.

[176] Goto Y, Suzuki K, Sasaki M, Ono T and Abe S. GK rat as a model of nonobese, noninsulin-dependent diabetes. Selective breeding over 35 generations. In: Frontiers in Diabetes Research. Lessons from Animal Diabetes II, edited by Renold AE and Renold. London, UK: John Libbey, 1988.

[177] Galli J, Li LS, Glaser A, Ostenson CG, Jiao H, Fakhrai-Rad H, Jacob HJ, Lander ES and Luthman H. Genetic analysis of non-insulin dependent diabetes mellitus in the GK rat. Nat Genet 12: 31-37, 1996.

[178] Almon RR, DuBois DC, Lai W, Xue B, Nie J and Jusko WJ. Gene expression analysis of hepatic roles in cause and development of diabetes in Goto-Kakizaki rats. J Endocrinol 200: 331-346, 2009.

[179] Galli J, Fakhrai-Rad H, Kamel A, Marcus C, Norgren S and Luthman H. Pathophysiological and genetic characterization of the major diabetes locus in GK rats. Diabetes 48: 2463-2470, 1999. 
[180] Porte DJ and Kahn SE. beta-cell dysfunction and failure in type 2 diabetes: potential mechanisms. Diabetes 50 Suppl 1: S160-S163, 2001.

[181] Xue B, Sukumaran S, Nie J, Jusko WJ, DuBois DC and Almon RR. Adipose tissue deficiency and chronic inflammation in diabetic goto-kakizaki rats. PLoS One 6: e17386, 2011.

[182] Chandler MP, Morgan EE, McElfresh TA, Kung TA, Rennison JH, Hoit BD and Young ME. Heart failure progression is accelerated following myocardial infarction in type 2 diabetic rats. Am J Physiol Heart Circ Physiol 293: H1609-H1616, 2007.

[183] Goto Y, Kakizaki M and Masaki N. Production of spontaneous diabetic rats by repetition of selective breeding. Tohoku J Exp Med 119: 85-90, 1976.

[184] Portha B. Programmed disorders of beta-cell development and function as one cause for type 2 diabetes? The GK rat paradigm. Diabetes Metab Res Rev 21: 495-504, 2005.

[185] Hughes SJ, Suzuki K and Goto Y. The role of islet secretory function in the development of diabetes in the GK Wistar rat. Diabetologia 37: 863-870, 1994.

[186] Svensson AM, Ostenson CG and Jansson L. Age-induced changes in pancreatic islet blood flow: evidence for an impaired regulation in diabetic GK rats. Am J Physiol Endocrinol Metab 279: E1139-E1144, 2000.

[187] Guenifi A, Simonsson E, Karlsson S, Ahren B and Abdel-Halim SM. Carbachol restores insulin release in diabetic GK rat islets by mechanisms largely involving hydrolysis of diacylglycerol and direct interaction with the exocytotic machinery. Pancreas 22: 164-171, 2001.

[188] Haynes WG, Sivitz WI, Morgan DA, Walsh SA and Mark AL. Sympathetic and cardiorenal actions of leptin. Hypertension 30: 619-623, 1997.

[189] Haynes WG, Morgan DA, Walsh SA, Sivitz WI and Mark AL. Cardiovascular consequences of obesity: role of leptin. Clin Exp Pharmacol Physiol 25: 65-69, 1998. 
